\title{
Plasminogen activators in normal tissue and carcinomas of the human oesophagus and stomach
}

\author{
C F M Sier, H W Verspaget, G Griffioen, S Ganesh, H J M Vloedgraven, C B H W Lamers
}

\begin{abstract}
Carcinogenesis in the human colon is associated with a marked increase of urokinase type plasminogen activator and a decrease of tissue type plasminogen activator. This study was performed to determine the concentrations of urokinase type plasminogen activator and tissue type plasminogen activator in normal tissue and carcinomas along the upper part of the gastrointestinal tract. Activity and antigen levels of both activators were determined in homogenates of endoscopically obtained biopsies from normal and carcinomatous tissues. Although the concentrations of tissue type plasminogen activator and urokinase type plasminogen activator in normal squamous epithelium of the oesophagus were low compared with those in columnar epithelium from the stomach, the urokinase type plasminogen activator/tissue type plasminogen activator antigen ratio of the different locations showed hardly any difference. Significant but heterogeneous increases were found in urokinase type plasminogen activator concentrations of biopsy specimens originating from carcinomas of both epithelial cell types. A decrease in tissue type plasminogen activator concentrations, as found in human colon carcinomas, could only be shown in carcinomas of columnar epithelium origin but not in squamous cell carcinomas of the oesophagus. The increase of urokinase type plasminogen activator and urokinase type plasminogen activator/tissue type plasminogen activator antigen ratio and the decrease of tissue type plasminogen activator in the carcinomas did not show a significant correlation with known prognostic determinants as differentiation grade, TNM classification, intestinal metaplasia, inflammation, and ulceration. The heterogeneous increase of urokinase type plasminogen activator in oesophageal and stomach carcinomas, together with the recently described association of urokinase type plasminogen activator in tissue extracts of breast carcinomas with aggressiveness and prognosis, may be of relevance to prognostic studies in oesophageal and gastric cancer.

(Gut 1993; 34: 80-85)
\end{abstract}

Plasminogen activators are involved in many protein degrading processes by converting plasminogen into the active enzyme plasmin. Tissue type plasminogen activator ( $t-P A)$ is a key enzyme in thrombolysis, while urokinase type plasminogen activator (u-PA) plays a major role in extracellular matrix breakdown related activities like tissue remodelling and tumour invasion. ${ }^{12}$ Tumour extracts of different origin such as breast, lung, prostate, stomach, and colon were found to have raised concentrations of plasminogen activator activities. Immunological characterisation revealed that most malignant cells and tissues predominantly produce urokinase type plasminogen activator rather than tissue type plasminogen activator depending on their origin..$^{1-8}$ Little is known, however, about plasminogen activators in solid tumours of the upper gastrointestinal tract. Early studies using crude fibrinolytic activity assays and histochemical fibrin slide techniques revealed plasminogen activators to be present in cancer tissue and cell lines obtained from the oral cavity and stomach. ${ }^{9-11}$ A significant increase of urokinase type plasminogen activator antigen in carcinomatous tissue extracts of oesophagus and stomach has recently been reported by Nishino et $a l,{ }^{12}$ while Takai $e t a l^{13}$ have found a significant increase of total plasminogen activator activity and urokinase type plasminogen activator activity in gastric carcinomas. Moreover, increased secretion of urokinase type plasminogen activator by gastrointestinal tumours has been shown by raised plasma and urine urokinase type plasminogen activator concentrations in patients with carcinomas of the pancreas, stomach, and colorectum. ${ }^{12-14}$ We have previously shown that adenocarcinomas of the colon have a five to 10fold increase in urokinase type plasminogen activator content accompanied by a three to five fold decrease of tissue type plasminogen activator, based on activity and antigen measurements. ${ }^{15}$ Comparison of plasminogen activator content between colon carcinoma resection tissue and endoscopically obtained biopsies of the same patients showed good agreement. In the same study a small group of six carcinomas of the stomach showed comparable results. ${ }^{16}$ The aim of the present study was to determine the concentrations of tissue type plasminogen activator and urokinase type plasminogen activator in carcinomas along the upper part of the gastrointestinal tract using endoscopical biopsies. For that purpose a comparison was made between plasminogen activator content of normal and carcinomatous biopsies of the oesophagus aligned with squamous epithelium, and of the distal oesophagus and different parts of the stomach aligned with columnar epithelium. 
Also the relation of plasminogen activator concentrations with histologically scored parameters such as differentiation grade, TNM classification, inflammation, ulceration, and intestinal metaplasia of the carcinomas was investigated.

\section{Methods}

\section{PATIENTS}

BIOPSIES

Normal mucosal biopsy specimens from three different locations of the upper gastrointestinal tract (squamous oesophagus, corpus/antrum, bulbus/duodenum) were taken during endoscopy from six dyspeptic patients without demonstrated pathology (two men, four women, age $45-48$ years). These biopsy specimens were confirmed endoscopically and histologically to have no signs of underlying disease. From patients with a carcinoma in the oesophagus or stomach ( 37 men, 10 women, age $49-88$ years) biopsy specimens were obtained from macroscopically suspected tissue and from normal mucosa $5-10 \mathrm{~cm}$ distal and/or proximal to the tumour. One male patient had two separate oesophageal carcinomas. The biopsies were immediately frozen at $-70^{\circ} \mathrm{C}$. For routine diagnostic purposes and for reference, adjacent biopsies were histologically examined by the pathologist and scored for inflammation, ulceration, intestinal metaplasia, and grade of differentiation. TNM classification of the carcinomas was performed, when possible, according to Hermanek and Sobin ${ }^{17}$ based on routine clinical evaluation. All patients included were histologically confirmed to have a carcinoma. The carcinomas were divided into two groups - that is, squamous cell carcinomas of the oesophagus and adenocarcinomas of the lower oesophagus and stomach, and for distinctness called respectively oesophageal and stomach carcinomas.

TISSUE EXTRACTION AND PROTEIN CONCENTRATION Biopsy specimens were homogenised in $1 \mathrm{ml}$ $0 \cdot 1 \%(\mathrm{v} / \mathrm{v})$ Tween $80 ; 0 \cdot 1 \mathrm{M}$ Tris- $\mathrm{HCl}(\mathrm{pH} 7 \cdot 5)$ per $25 \mathrm{mg}$ wet tissue as described before. ${ }^{16}$ The homogenate was centrifuged twice at $8000 \times g$ for
2.5 minutes, $4^{\circ} \mathrm{C}$. Protein concentration of the supernatants was determined by the method of Lowry et al. ${ }^{18}$

ENZYME LINKED IMMUNOADSORBENT ASSAY (ELISA) FOR UROKINASE TYPE PLASMINOGEN ACTIVATOR

The sandwich ELISA for urokinase type plasminogen activator was carried out according to Binnema et al. ${ }^{19}$ Rabbit anti-urokinase type plasminogen activator was used as catching antibody and after incubation of the samples, affinopurified goat anti-urokinase type plasminogen activator IgG $(0.8 \mu \mathrm{g} / \mathrm{ml})$ was added and incubated overnight. After washing, $100 \mu \mathrm{l}$ optimal dilution of rabbit anti-goat IgG conjugated with alkaline phosphatase was added and $100 \mu \mathrm{l}$ p-nitrophenyl-phosphate $(1 \mathrm{mg} / \mathrm{ml})$ was used as substrate. The amount of urokinase type plasminogen activator antigen in the samples was calculated from an eight point standard curve of urokinase type plasminogen activator $(0-5 \mathrm{ng} /$ $\mathrm{ml})$.

ELISA FOR TISSUE TYPE PLASMINOGEN ACTIVATOR Tissue type plasminogen activator antigen was measured essentially as described by Rijken et $a l{ }^{20}$ Rabbit anti-tissue type plasminogen activator was used as catching antibody, an antitissue type plasminogen activator horseradish peroxidase conjugate (Biopool, Sweden) as second antibody and $3,3^{\prime}, 5,5^{\prime}$ tetramethylbenzidine was used as substrate. Absolute quantities of tissue type plasminogen activator antigen in the samples were calculated from an eight point standard curve of tissue type plasminogen activator (Biopool, Sweden, 0-4 ng/ $\mathrm{ml})$.

\section{PLASMINOGEN ACTIVATORS ACTIVITY ASSAY}

Urokinase type plasminogen activator and tissue type plasminogen activator activities were measured by a spectrophotometric enzyme assay as described previously. ${ }^{15}$ In brief, tissue extract was incubated with plasminogen, fragments of fibrinogen and the chromogenic plasmin substrate S-2251 (Kabi, Stockholm) to detect total plasminogen activators activity. Tissue type

TABLE I Plasminogen activators in endoscopical biopsies from squamous oesophageal and stomach carcinomas compared with normal tissue biopsies from patients without [controls] or with [normal mucosa] carcinoma

\begin{tabular}{|c|c|c|c|c|c|c|c|c|}
\hline & \multicolumn{4}{|l|}{$t-P A$} & \multicolumn{4}{|c|}{$u-P A$} \\
\hline & $(n)$ & $\begin{array}{l}\text { Antigen } \\
\text { ng/mg protein }\end{array}$ & $(n)$ & $\begin{array}{l}\text { Activity } \\
\mathrm{mIU} / \mathrm{mg} \text { protein }\end{array}$ & (n) & $\begin{array}{l}\text { Antigen } \\
n g / m g \text { protein }\end{array}$ & $(n)$ & $\begin{array}{l}\text { Activity } \\
\text { mIU/mg protein }\end{array}$ \\
\hline \multicolumn{9}{|c|}{ Squamous oesophagus } \\
\hline Controls & [5] & $2 \cdot 0(0 \cdot 5)$ & [6] & $11(6)$ & [5] & $0.7(0 \cdot 2)$ & [6] & $4(2)$ \\
\hline Normal mucosa & [22] & $4 \cdot 1[1 \cdot 1)$ & {$[24]$} & $175(56) \dagger$ & [23] & $1.4(0.4)$ & {$[24]$} & $17(5)^{\star}$ \\
\hline Carcinoma & [16] & $4 \cdot 3(1 \cdot 0)$ & [16] & $299(155)$ & {$[16]$} & $18 \cdot 3(4 \cdot 5) \mathrm{S}$ & {$[16]$} & $60(23)$ \\
\hline \multicolumn{9}{|l|}{ Stomach } \\
\hline Controls & [12] & $6 \cdot 8(0 \cdot 6)+t$ & [12] & $1351(157)+t$ & [12] & $3 \cdot 9(0 \cdot 7)^{\star \star}$ & {$[12]$} & $40(8)^{\star \star}$ \\
\hline Normal mucosa & [29] & $7 \cdot 4(1 \cdot 3) 9$ & {$[30]$} & 1429 (179) tt & {$[30]$} & $1.8(0.3) \neq$ & {$[30]$} & $58(11)^{\star \star}$ \\
\hline Carcinoma & [32] & $5 \cdot 8(1 \cdot 5)$ & [32] & $442(88) \|$ & {$[32]$} & $12 \cdot 4(1 \cdot 4) \|$ & {$[32]$} & $78(14)$ \\
\hline \multicolumn{9}{|l|}{ Duodenum } \\
\hline Controls & [12] & $10 \cdot 1(1 \cdot 0) \dagger 十 \neq \ddagger$ & [12] & $2728(401)+t \$ S$ & [12] & $4 \cdot 2(0 \cdot 4)+t$ & [12] & $30(10) \uparrow$ \\
\hline
\end{tabular}

Results shown are mean values (SEM)

Significance of difference from control tissue: ${ }^{\star} \mathrm{p}<0.05 ; \mathrm{p}<0.01 ; \mathrm{p}<0.005$

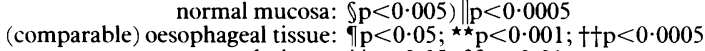

stomach tissue: $\neq \neq \mathrm{p}<0.05 ; \$ \$ \mathrm{p}<0 \cdot 01$

$\mathrm{t}-\mathrm{PA}=$ tissue type plasminogen activator. $\mathrm{u}-\mathrm{PA}=$ urokinase type plasminogen activator. 
plasminogen activator and urokinase type plasminogen activator activities were determined by adding specific inhibiting antibodies against tissue type plasminogen activator and urokinase type plasminogen activator, rabbit anti-human tissue type plasminogen activator IgG and goat antihuman urokinase type plasminogen activator IgG respectively, to parallel incubations and calculating the amount of inhibition. Urokinase type plasminogen activator and tissue type plasminogen activator standard preparations (National Institute of Biological Standards and Control, London, UK, batch nos. 66/46 and $83 / 517$ respectively) were included. The inhibiting antibodies used were monospecific, showed no cross reactivity, and blocked maximum standard urokinase type plasminogen activator and tissue type plasminogen activator activity completely.

\section{CALCULATIONS AND STATISTICAL ANALYSIS}

Activator activities were expressed as mIU urokinase type plasminogen activator or tissue type plasminogen activator per $\mathrm{mg}$ protein. Antigen concentrations were expressed as ng antigen per mg protein. Results are given as mean (SEM). Difference between group means were statistically tested for significance using paired and unpaired Student's $t$ test with separate variance estimate if the standard deviations were significantly different according to the F-test. Differences were considered significant when $\mathrm{p} \leq 0 \cdot 05$.

\section{Results}

The antigen and activity levels of both plasminogen activators in normal tissue showed a steady increase going from squamous oesophagus to the stomach and duodenum. Urokinase type plasminogen activator and tissue type plasminogen activator in squamous oesophagus were significantly lower than in the stomach. Duodenal tissue contained more tissue type plas-

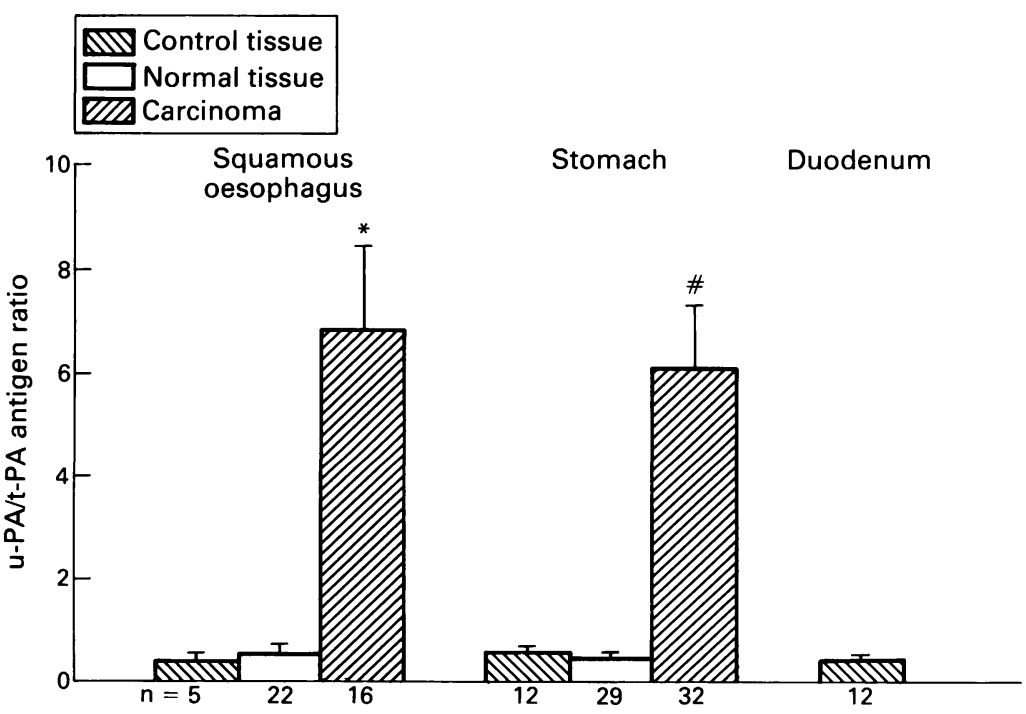

Figure 1: Urokinase type plasminogen activator/tissue type plasminogen activator antigen ratio in endoscopical biopsies from squamous oesophageal and stomach carcinomas compared with normal tissue from patients without (controls) or with a carcinoma. Significance of difference from normal tissue: ${ }^{\star} p<0.01 ; \# p<0.0001$. minogen activator than stomach tissue, but the concentration of urokinase type plasminogen activator in duodenal mucosa was found to be similar to that of the stomach (Table I). In general, the normal mucosa of the patients with a carcinoma showed a similar pattern although normal mucosa of squamous carcinomas contained higher concentrations of plasminogen activators, in particular based on activity, than corresponding normal mucosa of control patients. For urokinase type plasminogen activator antigen in the stomach the opposite was observed.

Urokinase type plasminogen activator antigen in carcinomas showed a six to seven fold increase in the stomach and a more than 13 fold higher concentration in oesophageal tissue compared with normal mucosa. Although in both carcinomas and normal mucosa urokinase type plasminogen activator antigen and activity showed a significant correlation (respectively, $R=0 \cdot 38$, $\mathrm{p}<0.01$ and $\mathrm{R}=0.41, \mathrm{p}<0.005$ ) and the activity of urokinase type plasminogen activator in carcinomas was higher than in normal mucosa, this difference did not reach statistical significance (Table I). Also with respect to tissue type plasminogen activator, antigen and activity were in general significantly correlated in carcinomas $(\mathrm{R}=0.58, \mathrm{p}<0.0001)$ and normal mucosa $(\mathrm{R}=0.32, \mathrm{p}<0.05)$. Moreover, tissue type plasminogen activator antigen as well as tissue type plasminogen activator activity in oesophageal carcinoma tissue were not different from normal tissue concentrations. Tissue type plasminogen activator in stomach carcinomas, however, showed a significant reduction in activity compared with normal stomach tissue, which was not seen in the tissue type plasminogen activator antigen concentration. The urokinase type plasminogen activator/tissue type plasminogen activator antigen ratio showed no differences between normal and control mucosa independent of the origin of the tissue. Carcinomas of the oesophagus and stomach had respectively 14 and 10 times higher ratios than normal tissues but were not different from each other (Fig 1). Urokinase type plasminogen activator antigen and the urokinase type plasminogen activator/ tissue type plasminogen activator antigen ratio of carcinoma tissue and the corresponding normal mucosa of the same patient are shown in Figure 2. Although all carcinomas contained more urokinase type plasminogen activator antigen than the matching normal tissues, the individual carcinoma samples showed great heterogeneity which was not associated with the localization. In 38 of the 39 tissue pairs tested the urokinase type plasminogen activator/tissue type plasminogen activator antigen ratio of the carcinomas was higher than the corresponding normal mucosa. Again considerable heterogeneity within the carcinomas was observed.

The heterogeneity in urokinase type plasminogen activator antigen and urokinase type plasminogen activator/tissue type plasminogen activator antigen ratio of the carcinomas, however, was not found to be related to differentiation, inflammation, metastasis formation, and the presence of intestinal metaplasia (Table II), although some minor differences between sub- 


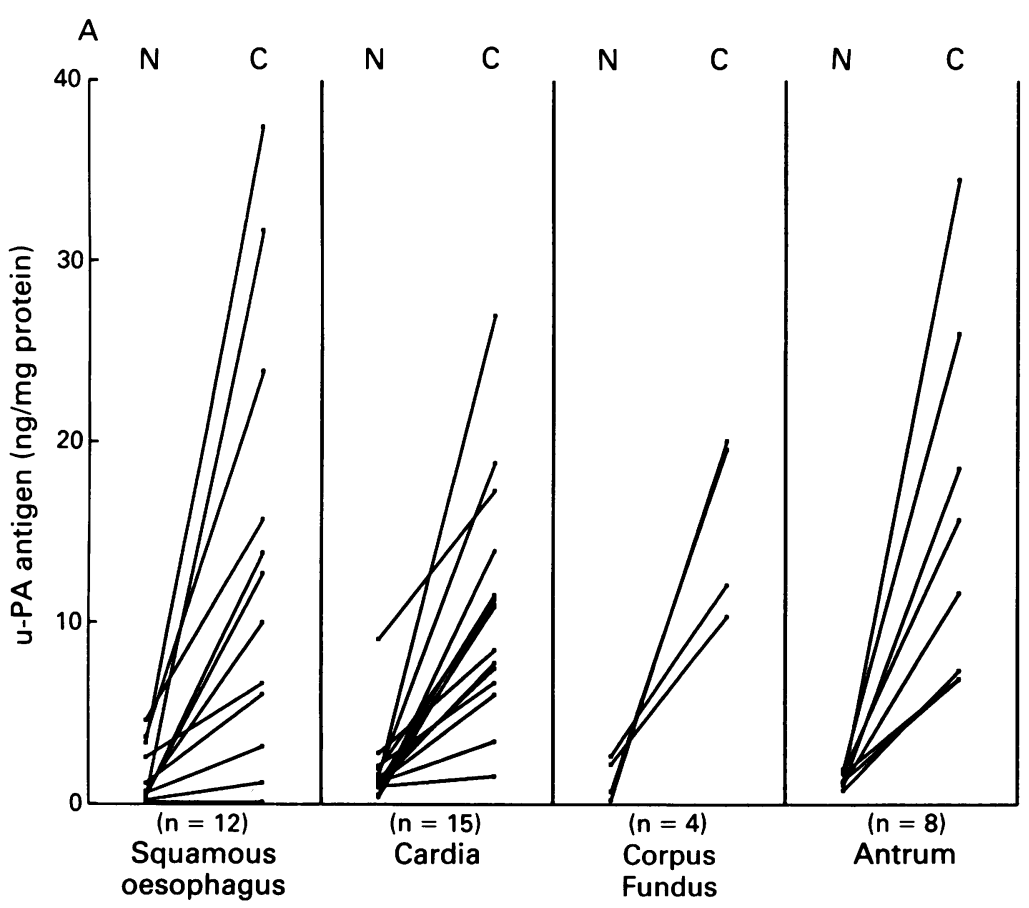

B

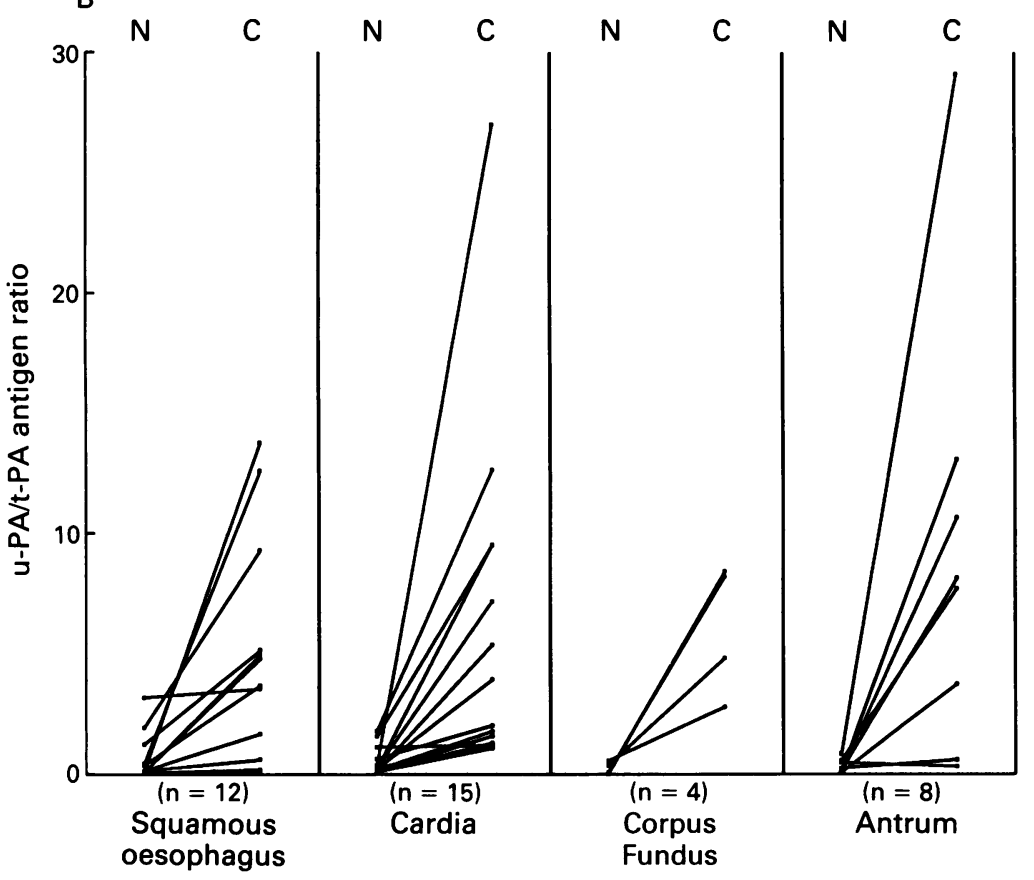

Figure 2(a) Urokinase type plasminogen activator antigen in endoscopical biopsies from patients with squamous oesophageal or stomach carcinomas $(N$ normal mucosa, $C$ corresponding carcinoma tissue); (b) urokinase type plasminogen activator/tissue type plasminogen activator antigen ratio in endoscopical biopsies of patients with squamous oesophageal or stomach carcinomas ( $N$ normal mucosa, $C$ corresponding carcinoma tissue). groups were observed. Moreover, dividing of the carcinomas into different stages according to the TNM Clinical Classification revealed no association between antigen or activity of both plasminogen activators and the clinical staging (data not shown).

\section{Discussion}

In this study a survey was made of the activity and antigen concentrations of plasminogen activators in normal mucosa biopsies obtained from three different locations of the upper gastrointestinal tract in control patients. At the same time a comparison was made of tissue type plasminogen activator and urokinase type plasminogen activator concentrations between normal mucosa and carcinoma tissue in endoscopical biopsies from patients with a carcinoma of the oesophagus or the stomach.

Oesophageal tissue was found to contain significantly less urokinase type plasminogen activator and tissue type plasminogen activator, both in antigen and activity, compared with stomach tissue. This remarkable difference in expression of plasminogen activators between both normal tissues is most likely caused by differences in the type of epithelium as squamous oesophageal tissue biopsies contain relatively more epithelium compared with columnar epithelial type tissues of the stomach because of its multilayer cell construction. The concentrations of urokinase type plasminogen activator in the duodenum resemble the quantities found in normal stomach tissue biopsy specimens. The increase of tissue type plasminogen activator antigen and activity in normal duodenal mucosa might be caused by a different vascularisation of the mucosa of this tissue, because tissue type plasminogen activator is expressed mainly in endothelial cells of vessels. ${ }^{11012}$ In the normal mucosa of patients with a carcinoma a similar increase in urokinase type plasminogen activator and tissue type plasminogen activator from oesophagus to stomach was observed as in controls.

Surprisingly, plasminogen activator antigen and activity levels of oesophageal and stomach carcinomas did not show significant differences between the two epithelial tissue types. With regard to the corresponding normal tissue, urokinase type plasminogen activator antigen concentrations in both carcinoma types were significantly higher and urokinase type plasminogen activator activities were also increased but not significantly. The tissue type plasminogen activator antigen concentrations in both oesophageal carcinomas and stomach carcinomas were similar to those of the normal tissues. In an immunohistochemical study of squamous cervical epithelia with dysplasia and (pre)invasive squamous cell carcinoma an increase in tissue type plasminogen activator concentration has been reported throughout the whole thickness of the epithelium. ${ }^{21}$ In the present study tissue type plasminogen activator activity in columnar carcinomas of the stomach, however, was significantly decreased. This decline was comparable with what we previously found in colon carcinomas. ${ }^{1516}$ The difference in alteration between tissue type plasminogen activator antigen and activity, and urokinase type plasminogen activator antigen and activity in columnar epithelial carcinomas has been seen before in colonic neoplasia ${ }^{15}$ and is a consequence of the complex regulation mechanism of the activity of both proteases. In colon carcinomas urokinase type plasminogen activator is predominantly found in the inactive proenzyme form (sc-u-PA), which can be activated in the presence of plasmin. An important role in the control of (pro)-urokinase type plasminogen activator catalyzed proteolysis is played by the urokinase type plasminogen activator receptor. ${ }^{22}$ 
TABLE II Urokinase type plasminogen activator activity and antigen, and urokinase type plasminogen activator/tissue type plasminogen activator antigen ratio in endoscopical biopsies from oesophagus and stomach carinomas

\begin{tabular}{lcccc}
\hline & $(n)$ & $\begin{array}{l}u-P A \text { activity } \\
\text { mIU/mg protein }\end{array}$ & $\begin{array}{l}u-P A \text { antigen } \\
n g / m g \text { protein }\end{array}$ & $\begin{array}{c}u-P A / t-P A \\
\text { antigen ratio }\end{array}$ \\
\hline Differentiation & 47 & & & \\
$\quad$ Well & 4 & $43(22)$ & $6 \cdot 5(3 \cdot 3)$ & $3 \cdot 5(2 \cdot 2)$ \\
$\quad$ Moderate & 20 & $58(19)$ & $19 \cdot 5(3 \cdot 7)$ & $8 \cdot 7(2 \cdot 3)$ \\
$\quad$ Poor & 23 & $91(18)$ & $11 \cdot 1(1 \cdot 3)^{\star}$ & $4 \cdot 7(0 \cdot 7)$ \\
Inflammation & 47 & & & \\
$\quad$ No inflammation & 15 & $73(23)$ & $11 \cdot 2(2 \cdot 6)$ & $3 \cdot 2(1 \cdot 1)$ \\
$\quad$ Inflammation & 12 & $59(19)$ & $12 \cdot 1(2 \cdot 0)$ & $4 \cdot 3(1 \cdot 0)$ \\
$\quad$ Ulceration & 20 & $81(21)$ & $17 \cdot 9(3 \cdot 5)$ & $9 \cdot 8(2 \cdot 1) \dagger \ddagger$ \\
Liver metastasis & 48 & & & \\
$\quad$ Absent & 13 & $82(24)$ & $13 \cdot 4(2 \cdot 3)$ & $7 \cdot 8(2 \cdot 0)$ \\
$\quad$ Present & 18 & $65(21)$ & $12 \cdot 5(2 \cdot 0)$ & $4 \cdot 7(1 \cdot 5)$ \\
$\quad$ Unknown & 17 & $71(19)$ & $16 \cdot 9(4 \cdot 3)$ & $7 \cdot 1(2 \cdot 0)$ \\
Intestinal metaplasia & 32 (only stomach) & & \\
$\quad$ Intestinal metaplasia & 8 & $117(38)$ & $14 \cdot 0(3 \cdot 2)$ & $8 \cdot 2(3 \cdot 4)$ \\
$\quad$ No intestinal metaplasia & 24 & $65(13)$ & $11 \cdot 8(1 \cdot 5)$ & $5 \cdot 4(1 \cdot 2)$ \\
\hline
\end{tabular}

Results shown are mean values (SEM).

Significance of difference from: ${ }^{\star}$ moderate differentiation $\mathrm{p}<0.05$

For abbreviations see Table I.
Plasminogen activator inhibitors also control the activity of both tissue type plasminogen activator and urokinase type plasminogen activator by forming inactive inhibitor enzyme complexes. ${ }^{23}$ Increased concentrations of these inhibitors have been found in plasma and ascitic fluid of patients with malignancies of the gastrointestinal tract or breast. ${ }^{1+2425}$ In colorectal carcinomas and in adenomatous polyps increased concentrations of plasminogen activator inhibitor type- 1 and type2 have been demonstrated concurrent with higher urokinase type plasminogen activator concentrations and inactivation of tissue type plasminogen activator. ${ }^{26}$ Enhanced urokinase type plasminogen activator activity and plasminogen activator inhibitor type-1 antigen concentrations were also found by Tanaka $e t a l^{27}$ in resected carcinomas of the colorectum and stomach, but plasminogen activator inhibitor type- 2 antigen concentrations were not increased in carcinomas. Thus, divergence of antigen and activity levels of the plasminogen activators is the consequence of a complex regulation cascade of proenzyme activation, receptor binding, and inactivation by inhibitors.

The heterogeneity, especially of the urokinase type of plasminogen activator concentration within the carcinomas, as shown in Figure 2a and $2 b$, could not be explained by the histologically scored parameters in this study. Classification of the carcinomas based on differentiation grade, inflammation, metastasis, and intestinal metaplasia did not reveal major differences in tissue type plasminogen activator or urokinase type plasminogen activator between subgroups. In contrast with the study of Takai et al ${ }^{13}$ the division of gastric cancer tissues into groups with different differentiation grades did not show a significant increase of plasminogen activator activities in well differentiated carcinomas. In fact, we found well differentiated carcinomas to contain significantly less urokinase type plasminogen activator antigen compared with poorly differentiated carcinomas (Table II). The high urokinase type plasminogen activator antigen and urokinase type plasminogen activator/tissue type plasminogen activator antigen ratio in ulcerating carcinomas was remarkable. This increase was not detected in the activity level of urokinase type plasminogen activator in the same carcinomas, which suggests the presence of pro-urokinase type plasminogen activator instead of active urokinase type plasminogen activator or complexes of urokinase type plasminogen activator with plasminogen activator inhibitors in this tissue.

Gastric cancer and especially oesophageal cancer are two of the most lethal gastrointestinal cancers in terms of cure rate and survival. It would be useful to be able to separate patients into good and poor prognostic groups. Many histological criteria have been analysed in resection material for their prognostic significance but were found to have little value. ${ }^{28}{ }^{29}$ Recent studies on breast carcinomas showed that high urokinase type plasminogen activator concentrations in tissue extracts are positively and independently associated with aggressiveness and poor prognosis while low tissue type plasminogen activator concentrations were found indicative for a shorter disease free interval and survival. $^{30-33}$ The heterogeneous increase of urokinase type plasminogen activator antigen concentrations in homogenates of endoscopical biopsy specimens from carcinomas of the upper gastrointestinal tract, which was not associated with several other prognostic determinants, as presented in this study, might perhaps be of value in determining prognosis in (early) oesophageal and gastric cancer.

The authors wish to thank Dr P A F de Bruin, Dr J H Verheijen, Dr G Dooijewaard, Marian Pijnenburg and the department of Pathology (Head: Prof Dr Hoedemaeker) for their assistance. We are also grateful to L Niepoth, N Koek en M Koster-de Vreese for typing the manuscript. This study was supported by a grant (IKW 89-9) from the Dutch Cancer Society (KWF).

1 Danø K, Andreasen PA, Grøndahl-Hansen J, Kristensen P, Nielsen LS, Skriver L. Plasminogen activators, tissue degradation, and cancer. Adv Cancer Res 1985; 44: 139-266.

2 Markus G. The relevance of plasminogen activators to neoplastic growth - a review of recent literature. Enzyme 1988; 40: 158-72.

3 Åstedt B, Holmberg L. Immunological identity of urokinase and ovarian carcinoma plasminogen activator released in and ovarian carcinoma plasminogen acti

4 Rifkin DB, Loeb JN, Moore G, Rerdi E. Properties of plasminogen activators formed by neoplastic human cell plasminogen activators formed by neopla

5 Tissot JD, Hauert J, Bachmann F. Characterization of plasminogen activators from normal human breast and colon and from breast and colon carcinomas. Int $\mathcal{f}$ Cancer 1984; 34 : 295-302.

6 Camiolo SM, Markus G, Evers JL, Hobika GH, DePasquale $\mathrm{JL}$, Beckley S, et al. Plasminogen activator content of neoplastic and benign human prostate tissues; fibrin augmentation of an activator activity. Int $\mathcal{F}$ Cancer 1981; 27: 191-8.

7 Markus G, Takita H, Camiolo SM, Corasanti JG, Evers JL, Hobika GH. Content and characterization of plasminogen activators in human lung tumors and normal lung tissue. Cancer Res 1980; 40: 841-8.

8 Quax PHA, van Leeuwen RTJ, Verspaget HW, Verheijen JH. Protein and messenger RNA levels of plasminogen Protein and messenger RNA levels of plasminogen
activators and inhibitors analyzed in 22 human tumor cell activators and inhibitors analyzed in

9 Szczepański M, Lucer C, Zawadzki J, Tolloczko T. Procoagulant and fibrinolytic activities of gastric and colorectal cancer. Int $\mathcal{F}$ Cancer 1982; 30: 329-33.

10 Ljungnér H, Björlin G, Âstedt B. Immunological identification of plasminogen activators in normal and malignant tissues of the oral cavity in man. Int $\mathcal{F}$ Oral Surg 1984; 13: 334-8.

11 Baici A, Sträuli P. Release of proteinases by cultures of human cell lines derived from squamous carcinomas of the tongue and larynx. Exp Cell Biol 1985; 53: 213-9.

12 Nishino N, Aoki K, Tokura Y, Sakaguchi S, Takada Y, Takada A. The urokinase type of plasminogen activator in cancer of digestive tracts. Thromb Res 1988; 50: 527-35.

13 Takai S, Yamamura M, Tanaka K, Kawanishi H, Tsuji M, Nakane $\mathrm{Y}$, et al. Plasminogen activators in human gastric cancers: correlation with DNA ploidy and immunohistochemical staining. Int $\mathcal{F}$ Cancer 1991; 48: 20-7. 
14 Kirchheimer JC, Huber K, Wagner O, Binder BR. Pattern of fibrinolytic parameters in patients with gastrointestinal fibrinolytic parameters in patients with
carcinomas. Br F Haematol 1987; 66: 85-9.

15 de Bruin PAF, Griffioen G, Verspaget HW, Verheijen JH, Dooijewaard $\mathrm{G}$, van den Ingh $\mathrm{HF}$, et al. Plasminogen activator profiles in neoplastic tissues of the human colon. Cancer Res 1988; 48: 4520-4.

16 de Bruin PAF, Verspaget HW, Griffioen G, Verheijen JH, Dooijewaard G, Lamers CBHW. Plasminogen activators in endoscopic biopsies as indicators of gastrointestinal cancer: comparison with resection specimens. BrF Cancer 1989; 60: 397-400.

17 Hermanek P, Sobin LH. International Union Against Cancer; TNM classification of malignant tumors. $4 \mathrm{th}$ ed. Berlin: Springer Verlag, 1987.

18 Lowry OH, Rosebrough NJ, Farr AL, Randall RJ. Protein measurement with the Folin phenol reagent. $f$ Biol Chem 1951; 193: 265-75.

19 Binnema DJ, van Iersel JJL, Dooijewaard G. Quantitation of urokinase antigen in plasma and culture media by use of an ELISA. Thromb Res 1986; 43: 569-77.

20 Rijken DC, van Hinsbergh VWM, Sens EHC. Quantitation of tissue-type plasminogen activator in human endothelial cel cultures by use of an enzyme immunoassay. Thromb Res 1984; 33: 145-53.

21 Larsson G, Larsson $\AA$, Åstedt B. Tissue plasminogen activator and urokinase in normal, dysplastic and cancerous squamous epithelium of the uterine cervix. Thromb Haemost 1987; 58: 822-6.

22 Blasi F. Surface receptors for urokinase plasminogen activator. Fibrinolysis 1988; 2: 73-84.

23 Sprengers ED, Kluft C. Plasminogen activator inhibitors. Blood 1987; 69: 381-7.

24 de Jong E, Knot EAR, Piket D, Iburg AHC, Rijken DC Veenhof $\mathrm{KHN}$, et al. Increased plasminogen activator inhibition levels in malignancy. Thromb Haemost 1987; 57 $140-3$.
25 Huber K, Wojta J, Kirchheimer JC, Ermler D, Binder BR. Plasminogen activators and plasminogen activator inhibitor in malignant and non-malignant ascitic fluid. Eur $\mathcal{F}$ Clin Invest 1988; 18 : 595-9.

26 Sier CFM, Verspaget HW, Griffioen G, Verheijen JH, Quax PHA, Dooijewaard G, et al. Imbalance of plasminogen activators and their inhibitors in human colorectal neoplasia; implication of urokinase in colorectal carcinogenesis. Gastroenterology 1991; 101: 1522-8.

27 Tanaka N, Fukao H, Ueshima S, Okada K, Yasutomi M, Matsuo O. Plasminogen activator inhibitor 1 in human carcinoma tissues. Int 7 Cancer 1991; 48: 481-4.

28 Edwards JM, Hillier VF, Lawson RAM, Moussalli $\mathrm{H}$, Hasleton PS. Squamous carcinoma of the oesophagus: histological criteria and their prognostic significance. Br f Cancer 1989; 59: 429-33.

29 Edwards JM, Jones DJ, Wilkes SJL, Hillier VF, Hasleton PS. Ploidy as a prognostic indicator in oesophageal squamous carcinoma and its relationship to various histological carcinoma and its relationship
criteria. F Pathol 1989; 159: 35-41.

30 Jänicke F, Schmitt $M$, Hafter R, Hollrieder A, Babic R, Ulm $\mathrm{K}$, et al. Urokinase-type plasminogen activator (u-PA) antigen is a predictor of early relapse in breast cancer. Fibrinolysis 1990; 4: 69-78.

31 Schmitt M, Jänicke F, Graeff $H$. Tumour-associated fibrinolysis: the prognostic relevance of plasminogen activators u-PA and t-PA in human breast cancer. Blood Coagulation and Fibrinolysis 1990; 1: 695-702.

32 Duffy MJ, O'Grady P, Devaney D, O'Siorain L, Fennelly JJ, Lijnen HR. Tissue-type plasminogen activator, a prognostic marker in breast cancer. Cancer Res 1988; 48: 1348-9.

33 Duffy MJ, Reilly D, O’Sullivan C, O'Higgins N, Fennelly JJ, Andreasen P. Urokinase-plasminogen activator, a new independent prognostic marker in breast cancer. Cancer Res 1990; 50: 6827-9. 